Jurnal Mutiara Akuntansi Vol. 6, No.2 (Desember 2021) 215-224

ISSN 2579-7611 (Online) | http://u.lipi.go.id/1487661056

\title{
Pengaruh Beban Pajak Tangguhan, Aktiva Pajak Tangguhan, Dan Akrual Terhadap Manajemen Laba Pada Perusahaan Aneka Industri Yang Terdaftar Di Bursa Efek Indonesia Periode 2015-2020
}

\author{
Owen De Pinto Simanjuntak ${ }^{1}$ \\ ${ }^{1}$ Program Studi Akuntansi, Fakultas Ekonomi dan Ilmu Sosial, Universitas Sari Mutiara Indonesia \\ e-mail : depintojuntak@gmail.com
}

\begin{abstract}
This study aims to determine the effect of deferred tax expense, deferred tax assets, and accruals on earnings management. The population in this study are various industrial companies listed on the Indonesia Stock Exchange for the 2015-2020 period. This research is a descriptive research with a quantitative approach. Data processing program using SPSS Version 25.By using 5 companies using purposive sampling. The data used in this study is secondary data, namely data on the financial statements of various industrial sector companies listedon the Indonesia Stock Exchange in the 2015-2020 period. The sample selection method used purposive sampling, namely the sampling method based on certain criteria. Of the 45 various industrialcompanies listed on the Indonesia Stock Exchange, there are only 5 companies that meet the research sample criteria that have been determined. The data analysis method used inthis research is multiple linear regression test, coefficient of determination $\left(R^{\wedge} 2\right)$ and correlation $(R)$, partial test ( $t$-test) and Simultaneous test $(F$-test) while earnings management is measured based on dummy variables. The results of this study indicate that deferred tax expense affects earnings management, deferred tax assets affect earnings management and accruals have no effect on earnings management.Based on the simultaneous test ( $F$ test) variable deferred tax expense, deferred tax assets andaccruals together have no effect on earnings management in various industrial companies listed on the Indonesia Stock Exchange in 2015-2020.
\end{abstract}

Keywords : Earnings Management, Deferred Tax Expense, Deferred Tax Assets, Accruals

\begin{abstract}
Abstrak
Penelitian ini bertujuan untuk mengetahui pengaruh dari Beban pajak tangguhan, Aktiva pajak tangguhan, dan Akrual terhadap Manajemen laba.Populasi dalam penelitian ini adalah perusahaan aneka industri yang terdaftar di Bursa Efek Indonesia periode 2015-2020.Penelitian ini adalah penelitian deskriptif dengan pendekatan kuantitatif.Program pengolahan data menggunakan program SPSS Versi 25.Dengan menggunakan 5 perusahaan yang menggunakan purposive sampling.Data yang digunakan dalam penelitian ini merupakan data sekunder, yaitu data laporan keuangan perusahaan aneka sektor industri yang terdaftar di Bursa Efek Indonesiay pada periode 2015-2020.Metode pemilihan sampel menggunakan purposive sampling, yaitu metode pengambilan sampel dengan berdasarkan kriteria tertentu.Dari 45 perusahan aneka industri yang terdaftar di Bursa Efek Indonesia, hanya ada 5 perusahaan yang memenuhi kriteria sampel penelitian yang telah ditetapkan.Metode analisis data yang digunakan dalam penelitian ini adalah uji regresi linear berganda, uji koefisien determinasi $\left(R^{2}\right)$ dan korelasi $(R)$, uji persial (uji-t) dan uji Simultan (uji $F$ ) sedangakan Manajemen laba diukur berdasarkan variabel dummy. Hasil penelitian ini menunjukan bahwa beban pajak tangguhan berpengaruh terhadap manajemen laba, aktiva pajak tangguhan berpengaruh terhadap manajemen laba dan akrual tidak berpengaruh terhadap manajemen laba.Berdasarkan uji simultan (uji F) variabel beban pajak tangguhan, aktiva pajak tangguhan dan akrual secara bersama-sama tidak memiliki berpengaruh terhadap manajemen laba pada perusahaan aneka industri yang terdaftar di Bursa Efek Indonesia pada tahun 2015-2020.
\end{abstract}

Kata Kunci : Manajemen Laba, Beban Pajak Tangguhan, Aktiva Pajak Tangguhan, Akrual

doi: https://doi.org/10.51544/jma.v6i2.2371

(C) 2021 Jurnal Mutiara Akuntansi. This is an open access article under the CC BY-SA license Website: http://e-journal.sari-mutiara.ac.id/index.php/JMA/ 


\section{PENDAHULUAN}

Laporan keuangan merupakan salah satu sumber informasi mengenai kondisi dan kinerja suatu perusahaan bagi pihak eksternal.Informasi tersebut menyangkut posisi keuangan, kinerja serta perubahan posisi keuangan suatu perusahaan, dan bermanfaat bagi sejumlah besar pemakai dalam pengambilan keputusan ekonomi.Oleh karena itu, perusahaan harus mampu menyajikan laporan keuangan yang berkualitas karena investor adalah pihak yang paling membutuhkan laporan keuangan.Salah satu elemen penting dalam laporan keuangan yang digunakan untuk mengukur kinerja manajemen adalah laba.

Terkait dengan informasi laba, statement of financial accounting concept (SFAC) No 1, Informasi laba merupakan perhatian utama untuk menaksir kinerja atau pertanggung jawaban manajemen. Selain itu informasi laba juga membantu pemilik atau pihak lain dalam menaksir earning power perusahaan di masa yang akan datang. Oleh karena itu manajemen mempunyai kecenderungan melakukantindakan untuk memberikan laporan keuangan yang atraktif. Sehingga informasi laba sering menjadi target rekayasa tindakan manipulasi laba (opportunistic management) untuk memaksimumkankepuasan manajer, tetapi akan merugikan pemegang saham atau investor. Tindakan kepentingan manajer tersebut dilakukan dengan cara memilih kebijakan akuntansi tertentu, sehingga laba perusahaan dapat diatur, dinaikkan maupun diturunkan sesuai dengan keinginannya. Perilaku manajer untuk mengatur laba sesuai keinginannya ini dikenal dengan istilah manajemen laba (Agustia, 2018:6).

Perusahaan di Indonesia menyusun laporan keuangan berpedoman pada PSAK dan Peraturan Perpajakan.Dalam menyiapkan laporan keuangan manajemen membutuhkan penilaian dan perkiraan, sehingga hal ini biasanya memberikan fleksibilitas dalam meyusun laporan keuangannya.Dan biasanya dalam penilaian laporan keuangan, laba sering dijadikan untuk sebagai dasar pembuatan besarnya pengenaan pajak.Oleh karena itu ada segelintir perusahaan yang mengutak-atik laba perusahaan sesuai keinginan pihak manajemen untuk mengurangi dalam pembayaran pajaknya.

Menurut Aditama dan Anna (2014), manajemen laba merupakan upaya yang dilakukan pihak manajemen untuk melakukan intervensi dalam penyusunan laporan keuangan dengan tujuan untuk menguntungkan dirinya sendiri, yaitu pihak perusahaan yang terkait.Upaya intervensi ini menyebabkan laporan keuangan tidak lagi mencerminkan kondisi sesungguhnya suatu perusahaan sehingga menimbulkan asimetri informasi, yaitu kondisi dimana ada ketidakseimbangan perolehan informasi antara pihak manajemen sebagai penyedia informasi dengan pemegang saham dan stakeholders. Dengan demikian sedapat mungkin apa yang dilaporkan perusahaan mendekati hal sesungguhnya terjadi, baik untuk laporan pajak maupun laporan kepada investor (Astutik dan Titik, 2016).

Permasalahan yang terjadi selama beberapa dekade dengan semakin maraknya kasus-kasus penyimpangan korporasi yang terjadi di seluruh dunia, yaitu manajemen laba, alasannya: pertama, manajemen laba seolah-olah telah menjadi budaya perusahaan (corporate culture).Hal ini tentu sangat merugikan semua pihak, termasuk pihak yang mempunyai hubungan secara langsung dengan perusahaan tersebut.Kedua, penyimpangan korporasi sebenarnya tidak hanya dilakukan oleh manajer perusahaan tetapi melibatkan pemilik (owner), auditor internal, komisaris, regulator (pemerintah dan asosiasi profesi) dan akuntan publik.Ketiga, kasus penyimpangan itu tidak hanya terjadi di negara - negara berkembang yang sistem bisnisnya memang belum terbangun dengan baik, namun juga di negara-negara maju yang sistemnya relatif telah tertata dengan baik (Sulistyanto, 2012:12).

Fenomena adanya praktik manajemen laba sering terjadi, sebagai contoh yaitu dalam kasus PT Garuda Indonesia, ternyata sejak bulan Juni 2015 keuangan PT Garuda Indonesia sudah dimanipulasi. PT Garuda Indonesia (persero) diduga melakuakan perubahan dalam laporan keuangan agar terlihat sehat. Dugaan perubahan ini terlihat dari salinan percakapan sebuah grup 
Whatsapp (baca:WA). Di dalam salinan percakapan itu sangat terlihat jajaran direksi atau BOD memberikan perintah kepada kepala unit dan kepala bagian akunting PT Garuda Indonesia untuk memundurkan semua pembayaran hutang.Pemunduran ini dimaksudkan membuat laporan keuangan menjadi bagus. Dalam bait pertama, direktur keuangan (DF) menugaskan untuk melakukan identifikasi biaya-biaya non rutin bulan Juni 2015, agar dapat direvisi lebih maju bulan Juli atau Agustus 2015. Namun cara ini dengan syarat tidak mengganggu oprasional secara signifikan. Selanjutnya, jika kesepakatan pengunduran hutang telah disepakati terutama dalam bentuk perjanjian, maka bisa direvisi untuk ditandatangani ulang dan akan efektif bulan Juli atau Agustus. Disini bukan hanya negosiasi pembayaran saja melainkan efektivitas perjanjian dan transaksinya.Diakhir percakapan, sangat tegas penyataan yang dikatakan di WA. Dimana seluruh karyawan yang ditugaskan perintahtersebuttidak melaksanakannya,maka akan mendapatkan teguran keras dari jajarandireksi. (www.energyworld.co.id).

Perkara manajemen laba terbaru di Indonesia merupakan kasus manajemen laba PT. Garuda Indonesia (Persero) Tbk pada tahun 2018. PT. Garuda Indonesia (Persero) menerbitkan laporan keuangan yang menunjukkan laba bersih USD 809,85 ribu dimana pada laporan keuangan tahun 2017 PT. Garuda Indonesia (Persero) masih memiliki rugi sebesar USD 216,5 juta (Hartomo, 2019). Setelah diselidiki dimana kejadiaan ini pelaporan PT. Garuda Indonesia (Persero) pada tahun 2018 tidak sesuai dengan peraturan PSAK.Auditor eksternal perusahaan adalah Akuntan Publik Kasner Sirumapea yang bekerja di Kantor Akuntan Publik Tanubrata Sutanto Fahmi Bambang \& Rekan (Member of BDO International) juga mendapatkan sanksi dari Kementerian Keuangan (Hartomo, 2019).

Salah satu motivasi perusahaan melakukan manajemen laba adalah pajak.Bagi sebuah negara pajak merupakan aspek penting dalam pembangunan, apalagi bagi negara berkembang seperti Indonesia. Tanpa pajak kehidupan negara tidak akan berjalan dengan baik. Tidak bisa dipungkiri lagi bahwa salah satu penopang pendapatan nasional yaitu berasal dari penerimaan pajak. Bagi suatu perusahaan, pajak yang ditanggung merupakan suatu elemen biaya yang mengurangi laba perusahaan, karena semakin tinggi pajak yang ditanggung oleh suatu perusahaan berarti semakin kecil pula laba yang akan didapatkan perusahaan tersebut, sehingga timbul suatu kecenderungan untuk meminimalkan pembayaran pajak.

Manajemen sering memanfaatkan peluang untuk memainkan angka laba dalam rangka mempengaruhi hasil akhir dari berbagai keputusan, salah satu contohnya manajemen berusaha meminimalkan pajak yang semestinya mereka bayar, dengan cara meningkatkan akrual untuk menjadikan angka laba lebih rendah. Jumlah pajak terutang dihitung berdasarkan besar kecilnya laba yang diperoleh perusahaan setiap tahunnya dikalikan dengan tarif pajak yang berlaku.Karena pajak berhubungan langsung dengan laba, di mana laba sering digunakan sebagai dasar untuk pembuatan keputusan berbagai pihak yang berkepentingan, maka manajemen memanfaat peluang untuk melakukan manajemen laba dengan rekayasa akrual untuk meminimalkan jumlah pajak (Astutik, 2016).

Beberapa penelitian telah dilakukan untuk mencoba mengkaji permasalahan mengenai manajemen laba dalam hubungannya dengan perpajakan perusahaan.Penelitian yang dilakukan oleh Tundjung (2015) dan Astutik (2016) membuktikan bahwa beban pajak tangguhan berpengaruh signifikan terhadap manajemen laba.

Adapun penelitian yang berhubungan tentang pengaruh beban pajak tangguhan terhadap manajemen laba masih memberikan hasil yang tidak konsisten diantaranya Timuriana dan Rezwan (2015) yang menemukan bukti bahwa beban pajak tangguhan tidak berpengaruh terhadap manajemen laba, namun hasil yang berbeda dengan penelitian yang dilakukan oleh Hakim dan Sugeng (2015) yang menemukan bukti bahwa beban pajak tangguhan berpengaruh signifikan terhadap manajemen laba. 
Hubungan antara beban pajak tangguhan, aktiva pajak tangguhan dan akrual sangat erat dalam mendeteksi perilaku dari earning management yaitu untuk memaksimumkan bonus yang mereka dapatkan dengan merekayasa angka akrual dan berusaha meminimalkan pajak yang mesti mereka bayarkan, dengan cara meningkatkan akrual untuk menjadikan angka laba lebih rendah. Pengakuan pajak tangguhan dapat mengakhibatkan bertambah atau berkurangnya laba bersih karena adanya pengakuan beban pajak tangguhan atau manfaat pajak tangguhan.Pengakuan aktiva dan pajak tangguhan didasarkan pada fakta adanya kemungkinan pembayaran pajak pada periode mendatang menjadi lebih besar atau lebih kecil.Hal ini, menjadi celah bagi manajemen untuk memanipulasi jumlah dari laba bersihnya sehingga bisa memperkecil jumlah pajak yang harus dibayar.

Kasus manajemen laba di Indonesia memang sering terjadi, yang merusak etika, moral, dan yang paling penting yaitu tingkat kepercayaan eksternal dengan kualitas laporan keuangan yang disajikan (Febriani, 2014). Teknik dan cara melaksanakan manajemen laba juga berbeda seperjalanan berkembangnya jaman, makanya manajemen laba harus dilanjutkan dipelajari agar dapat mencegah ataupun meminimalisir terjadinya kasus manajemen laba di Indonesia (Mutiarasari, 2016).

\section{METODE PENELITIAN}

Menurut Sugiyono (2015:38) objek penelitian adalah suatu atribut atau nilai dari orang.Objek atau kegiatan yang mempunyaivariasi tertentu yang ditetapkan oleh peneliti untuk dipelajari dan kemudian ditarik kesimpulannya. Dan menurut Sugiyono (2015:2) metode penelitian adalah cara ilmiah untuk mendapatkan data dengan tujuan dan kegunaan tertentu. Dalam penelitian ini, penulis menggunakan metode penelitian kuantitatif.Penelitian kuantitatif adalah penelitian yang dilakukan dengan mengumpulkan data yang berupa angka, atau data berupa kata-kata atau kalimat yang diubah menjadi data yang berbentuk angka.

\section{HASIL DAN PEMBAHASAN}

\section{HASIL}

\section{Statistik Deskriptif Variabel Penelitian}

Statistik deskriptif memberikan gambaran mengenai nilai minimum, nilai maksimum, nilai rata-rata, dan standart deviasi untuk data yang digunakan dalam penelitian.Nilai minimum merupakan nilai terkecil yang diambil dari suatu variabel.Nilai maksimum merupakan nilai terbesar yang diambil dari suatu variabel.Nilai rata-rata merupakan suatu besaran yang mewakili sekumpulan data.Standar deviasi adalah nilai statistik yang digunakan untuk menentukan bagaimana sebaran data dalam sampel, dan seberapa dekat titik data individuke mean atau rata rata nilai sampel.

1) Variabel Beban Pajak Tangguhan memiliki jumlah sampel sebanyak 30, dengan nilai minimum -19085477.00 yaitu pada Voksel Electric Tbk pada tahun 2016 dan nilai maksimum 73231744.00 yaitu pada Multi Prima Sejahtera Tbk pada tahun 2016 sedangkan nilai rata-rata (mean) 4570392.2333dengan standar deviasi 16269022.63150.

2) Variabel Aktiva Pajak Tangguhan memiliki jumlah sampel sebanyak 30, dengan nilai minimum -5039177477.00yaitu pada Garuda Metalindo Tbk pada tahun 2015 dan nilai maksimum 824203571.00 yaitu pada Garuda Metalindo Tbk pada tahun 2016, sedangkan nilai rata - rata ( mean ) yaitu -242979036.6667dengan standar deviasi 1370383659.67633.

3) Variabel Akrual memiliki jumlah sampel sebanyak 30, dengan nilai minimum -831112184.765 yaitu pada KMI Wire dan Cable Tbk pada tahun 2020 dan nilai maksimum 430003823.265 yaitu pada KMI Wire dan Cable Tbk pada tahun 2019 sedangkan nilai rata - rata (mean) 12216987510.2333dengan standar deviasi217987305514.97870. 
4) Variabel Manajemen Laba memiliki jumlah sampel sebanyak 30, dengan nilai minimum 0 pada KMI Wire dan Cable Tbk pada tahun 2018,2020 pada Voksel Electric Tbk pada tahun 2018,2020 pada Multi Prima Sejahtera Tbk pada tahun 2016,2018,2019,2020 pada Indospring Tbk tahun 2018,2019,2020, pada Garuda Metalindo Tbk pada tahun2015,2017,2018,2019,2020. Dan nilai maksimum 1 yaitu pada KMI Wire dan Cable Tbk pada tahun 2016,2017,2019 pada Voksel Electric Tbk pada tahun 2016,2017,2019 pada Multi Prima Sejahtera Tbk pada tahun 2017 pada Indospring Tbk tahun 2016,2017 pada Garuda Metalindo Tbk 2016. Sedangkan nilai rata - rata (mean) 0,40 dengan standar deviasi 0,500.

\section{Uji Autokorelasi}

Model Summary

\begin{tabular}{|l|r|r|r|r|r|}
\hline Model & $\mathrm{R}$ & R Square & Adjusted R Square & $\begin{array}{c}\text { Std. Error of the } \\
\text { Estimate }\end{array}$ & Durbin-Watson \\
\hline 1 & $.473^{\mathrm{a}}$ & .223 & .086 & .462 & 1.344 \\
\hline
\end{tabular}

a. Predictors: (Constant), Akrual, Beban pajak tangguhan, Aktiva pajak tangguhan

b. Dependent Variable: Manajemen laba

\section{Uji Multikolinearitas}

Coefficients $^{\mathrm{a}}$

\begin{tabular}{|c|c|c|c|c|c|c|c|c|}
\hline \multirow{2}{*}{\multicolumn{2}{|c|}{ Model }} & \multicolumn{2}{|c|}{ Unstandardized Coefficients } & \multirow{2}{*}{$\begin{array}{c}\begin{array}{c}\text { Standardize } \\
\text { d }\end{array} \\
\text { Coefficients }\end{array}$} & \multirow[b]{2}{*}{$t$} & \multirow[b]{2}{*}{ Sig. } & \multicolumn{2}{|c|}{$\begin{array}{c}\text { Collinearity } \\
\text { Statistics }\end{array}$} \\
\hline & & B & $\begin{array}{l}\text { Std. } \\
\text { Error }\end{array}$ & & & & Tolerance & VIF \\
\hline \multirow[t]{4}{*}{1} & (Constant) & .186 & .122 & & 1.515 & .148 & & \\
\hline & Beban pajak tangguhan & .00005968 & .000 & .412 & 1.799 & .090 & .870 & 1.149 \\
\hline & Aktiva pajak tangguhan & .0000005865 & .000 & .413 & 1.788 & .092 & .855 & 1.170 \\
\hline & Akrual & .0000000003345 & .000 & .076 & .340 & .738 & .923 & 1.083 \\
\hline
\end{tabular}

a. Dependent Variable: Manajemen laba

\section{Uji Heteroskedastisitas}

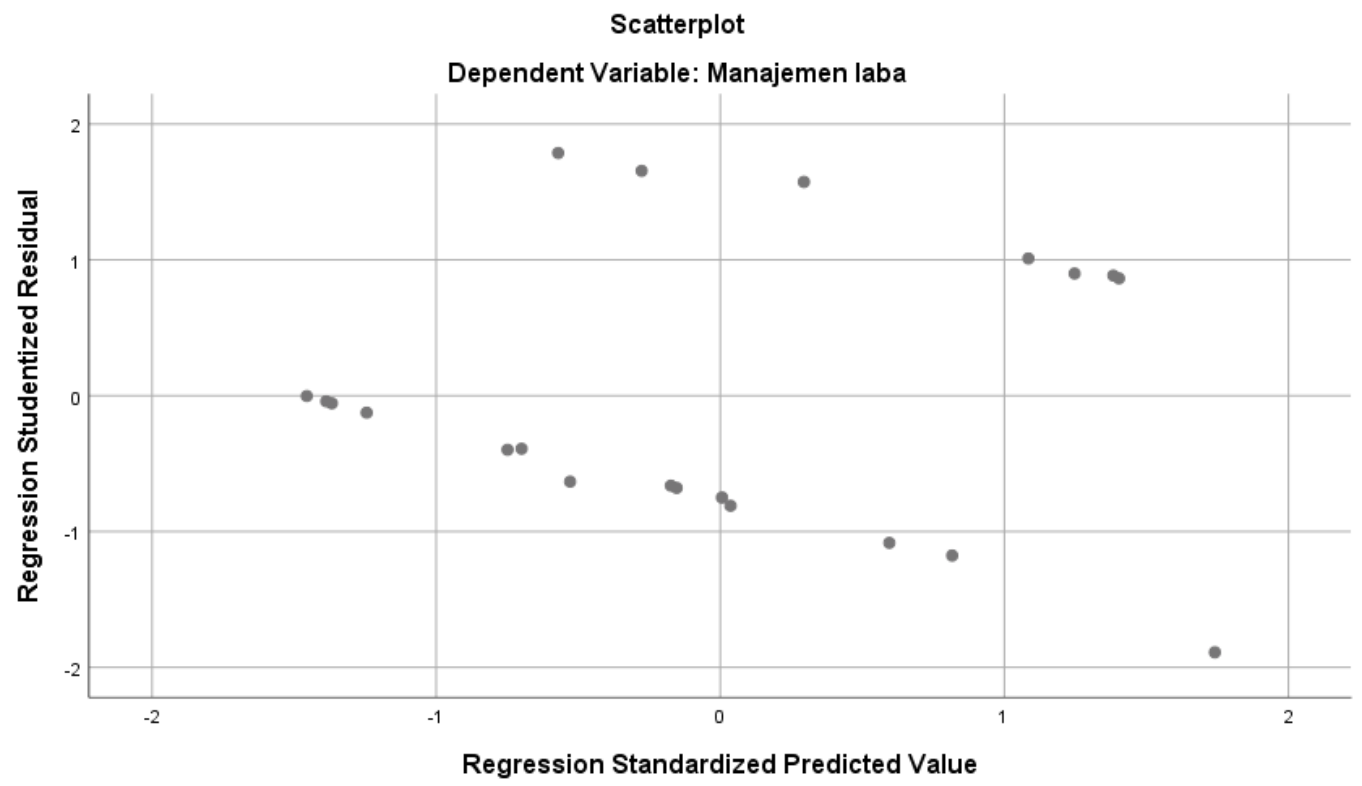

Hasil pengujian heteroskedastisitas menunjukkan bahwa titik-titik yang tidak membentuk pola tertentu atau tidak ada pola yang jelas serta titik - titik menyebar di atas dan dibawah angka 0 (nol) pada sumbu Y, maka tidak terjadi heteroskedastisitas 


\section{Regresi Linier Berganda}

\section{Coefficients $^{a}$}

\begin{tabular}{|c|c|c|c|c|c|c|}
\hline \multirow{2}{*}{\multicolumn{2}{|c|}{ Model }} & \multicolumn{2}{|c|}{ Unstandardized Coefficients } & \multirow{2}{*}{$\begin{array}{c}\begin{array}{c}\text { Standardized } \\
\text { Coefficients }\end{array} \\
\text { Beta }\end{array}$} & \multirow[b]{2}{*}{$\mathrm{t}$} & \multirow[b]{2}{*}{ Sig. } \\
\hline & & B & $\begin{array}{l}\text { Std. } \\
\text { Error }\end{array}$ & & & \\
\hline \multirow[t]{4}{*}{1} & (Constant) & .186 & .122 & & 1.515 & .148 \\
\hline & Beban pajak tangguhan & .00005968 & .000 & .412 & 1.799 & .090 \\
\hline & Aktiva pajak tangguhan & .0000005865 & .000 & .413 & 1.788 & .092 \\
\hline & Akrual & .0000000003345 & .000 & .076 & .340 & .738 \\
\hline
\end{tabular}

a. Dependent Variable: Manajemen laba

\section{Hipotesis}

Uji Signifikan Parameter Individual (Uji-t)

Coefficients $^{\mathrm{a}}$

\begin{tabular}{|c|c|c|c|c|c|c|}
\hline \multirow{2}{*}{\multicolumn{2}{|c|}{ Model }} & \multicolumn{2}{|c|}{ Unstandardized Coefficients } & \multirow{2}{*}{$\begin{array}{c}\begin{array}{c}\text { Standardized } \\
\text { Coefficients }\end{array} \\
\text { Beta }\end{array}$} & \multirow[b]{2}{*}{$\mathrm{t}$} & \multirow[b]{2}{*}{ Sig. } \\
\hline & & - & $\begin{array}{l}\text { Std. } \\
\text { Error }\end{array}$ & & & \\
\hline \multirow[t]{4}{*}{1} & (Constant) & .186 & .122 & & 1.515 & .148 \\
\hline & Beban pajak tangguhan & .00005968 & .000 & .412 & 1.799 & .090 \\
\hline & Aktiva pajak tangguhan & .0000005865 & .000 & .413 & 1.788 & .092 \\
\hline & Akrual & .0000000003345 & .000 & .076 & .340 & .738 \\
\hline
\end{tabular}

a. Dependent Variable: Manajemen laba

\section{Signifikan Parameter Simultan (Uji-F)}

\section{ANOVA $^{\mathrm{a}}$}

\begin{tabular}{|l|l|r|r|r|r|r|}
\hline \multicolumn{2}{|l|}{ Model } & Sum of Squares & $\mathrm{df}$ & Mean Square & F & Sig. \\
\hline \multirow{3}{*}{1} & Regression & 1.042 & 3 & .347 & 1.629 & $.220^{\mathrm{b}}$ \\
\cline { 2 - 7 } & Residual & 3.625 & 17 & .213 & & \\
\cline { 2 - 7 } & Total & 4.667 & 20 & & & \\
\hline
\end{tabular}

a. Dependent Variable: Manajemen laba

b. Predictors: (Constant), Akrual, Beban pajak tangguhan, Aktiva pajak tangguhan

\section{Uji Korelasi r dan Determinasi $\left(\mathbf{R}^{2}\right)$}

\begin{tabular}{|l|r|r|r|r|r|}
\multicolumn{7}{|c|}{ Model Summary } \\
\hline Model & $\mathrm{R}$ & R Square & Adjusted R Square & $\begin{array}{c}\text { Std. Error of the } \\
\text { Estimate }\end{array}$ & Durbin-Watson \\
\hline 1 & $.473^{\mathrm{a}}$ & .223 & .086 & .462 & 1.344 \\
\hline
\end{tabular}

a. Predictors: (Constant), Akrual, Beban pajak tangguhan, Aktiva pajak tangguhan

b. Dependent Variable: Manajemen laba

\section{PEMBAHASAN}

Hasil temuan dalam penelitian ini adalah mengenai hasil temuan penelitian ini terhadap kesesuaian teori, pendapat maupun penelitian terdahulu yang telah dikemukakan hasil penelitian sebelumnya serta pola perilaku yang harus dilakukan untuk mengatasi hal-hal tersebut. Berikut ini 
ada tiga bagian utama yang akan dibahas dalam analisis hasil temuan penelitian ini, yaitu sebagai berikut:

\section{a) Pengaruh Beban pajak tangguhanterhadap Manajemen Laba}

Menurut Harnanto (2003: 115), beban pajak tangguhan adalah beban yang timbul akibat perbedaan temporer antara laba akuntansi (laba dalam laporan keuangan untuk pihak eksternal) dengan laba fiskal (laba yang digunakan sebagai dasar perhitungan pajak). Perbedaan antara laporan keuangan akuntansi dan fiskal disebabkan dalam penyusunan laporan keuangan, standar akuntansi lebih memberikan keleluasaan bagi manajemen dalam menentukan prinsip dan asumsi akuntansi dibandingkan yang diperbolehkan menurut peraturan pajak (Yulianti, 2005).Dalam penelitian ini menyatakan bahwa variabel Beban Pajak Tangguhan secara parsial berpengaruh signifikan terhadap Manajemen Laba pada perusahaan sektor aneka industri yang terdaftar di Bursa Efek Indonesia tahun 2015 - 2020. Dimana hasil output SPSS uji statistik tdiperoleh nilai t hitung $=$ $1,799>\mathrm{t}$ tabel 1,70562.Hal ini berarti hubungan antara Beban Pajak Tangguhan terhadap Manajemen Laba berpengaruh signifikan.

Hasil penelitian ini di dukung dengan penelitian terdahulu Kharifah (2019), Hilmy (2020) dan Masero (2020). Ketiga penelitian ini menyatakanbahwa adanya pengaruh antara beban pajak tangguhan terhadap manajemen laba. Penelitian ini juga bertentangan dengan penelitian terdahulu Anggraini (2018) dan Khalifah (2019) yang menyatakan bahwa tidak adanya pengaruh positif signifikan antara beban pajak tangguhan terhadap manajemen laba.

\section{b) Pengaruh Aktiva Pajak Tangguhan terhadap Manajemen Laba}

Aktiva pajak tangguhan adalah jumlah pajak penghasilan terpulihkan pada periode masa depan sebagai akibat adanya perbedaan temporer yang dapat dikurangkan, akumulasi rugi pajak belum dikompensasi dan akuntansi kredit pajak belum dimanfaatkan. Aktiva pajak tangguhan memungkinkan perusahaan memanfaatkan celah dalam merekayasa laporan keuangannya.Dimana aktiva pajak tangguhan jumlahnya diperbesar oleh manajemen dengan dimotivasi adanya pemberian bonus, beban politis atas besarnya perusahaan sehingga memotivasi pihak perusahaan dalam melakukan manajemen laba.

Dalam penelitian ini menyatakan bahwa variabel Aktiva Pajak Tangguhan secara parsial berpengaruh signifikan terhadap Manajemen laba pada perusahaan sektor aneka industri yang terdaftar di Bursa Efek Indonesia tahun 2015 - 2020. Dimana hasil output SPSS uji statistik t diperoleh nilai t hitung 1,788> t tabel 1,70562.Hal ini berarti hubungan antara Aktiva Pajak Tangguhan terhadap Manajemen Laba berpengaruh signifikan.

Hasil penelitian ini bertentangan dengan penelitian terdahulu Anggraini (2018) ,Lauwardi (2020) dan Masero (2020) yang menyatakan bahwa tidak adanya pengaruh aktiva pajak tangguhan terhadap manajemen laba.

\section{c) Pengaruh Akrual terhadap Manajemen Laba}

Menurut Mahmudi $(2016,135)$ menyatakan bahwa: “Akuntansi Akrual merupakan teknik pencatatan akuntansi yang secara luas digunakan pada organisasi bisnis. Akuntansi Akrual mengakui transaksi pada saat terjadinya, yaitu ketika sudah terjadi perpindahan hak dan kewajiban, bukan berdasarkan diterima atau dikeluarkan kasnya.Dengan akuntansi akrual, organisasi mengakui dan mencatat pendapatan, biaya, utang, piutang, dan asset secara lebih komprehensif dibandingkan akuntansi kas".Manajemen laba dapat dilakukan dengan mempermainkan komponen - komponen akrual dalam laporan keuangan, sebab akrual merupakan komponen yang mudah untuk dipermainkan sesuai dengan keinginan orang yang melakukan pencatatan transaksi dan menyusun laporan keuangan.Alasannya, komponen akrual merupakan komponen yang tidakmemerlukan bukti kas secara fisik sehingga upaya mempermainkan besar kecilnya komponen akrual tidak harus disertai dengan kas yang diterima atau dikeluarkan perusahaan.

Dalam penelitian ini menyatakan bahwa variabel Akrual tidak berpengaruh signifikan terhadap manajemen laba pada perusahaan sektor aneka industri yang terdaftar di Bursa Efek Indonesia tahun 2016 - 2020. Dimana hasil output SPSS uji statistik tdiperoleh nilai t hitung 0,340 $<$ nilai t tabel 1,70562. Hal ini berarti hubungan antara Akrual terhadap Manajemen Laba tidak 
berpengaruh. Laba akrual merupakan laba bersih operasi yang didasarkan pada perhitungan akrual, non discretionary accruals merupakan laba akrual yang wajar yang tidak dipengaruhi kebijakan manajemen,serta tunduk pada suatu standar atau prinsip akuntansi yang berlaku umum, dan jika standar tersebut dilanggar akan mempengaruhi kualitas laporan keuangan sedangkan discretionary accruals adalah tingkat laba yang tidak normal yang merupakan pilihan manajemen. Akan tetapi bukan berarti akrual berpengaruh terhadap manajemen laba hal ini dibuktikan dalam penelitian ini serta di dukung dengan hasil penelitian terdahulu oleh Lauwardi (2020) yang menyatakan bahwa akrual tidak berpengaruh terhadap manajemen laba.

\section{KESIMPULAN DAN SARAN}

Berdasarkan hasil peneletian dan kajian yang telah diuraikan sebelumnya, maka dapat disimpulkan menjadi beberapa hal sebagai berikut :

1) Variabel Beban pajak tangguhan $\left(\mathrm{X}_{1}\right)$ berpengaruh signifikan terhadap Manajemen laba (Y) pada perusahan sektor aneka industry yang terdaftar di Bursa Efek Indonesia pada tahun 2015 2020.

2) Variabel Aktiva pajak tangguhan $\left(\mathrm{X}_{2}\right)$ berpengaruh signifikan terhadap manajemen laba $(\mathrm{Y})$ pada perusahan sektor aneka industri yang terdaftar di Bursa Efek Indonesia pada tahun 2015 2020.

3) Variabel Akrual (X3) tidak berpengaruh signifikan terhadap manajemen laba (Y) pada perusahan sektor aneka industri yang terdaftar di Bursa Efek Indonesia pada tahun 2015 - 2020.

4) Variabel Beban pajak tangguhan $\left(X_{1}\right)$ Aktiva pajak tangguhan $\left(X_{2}\right)$ dan Akrual $(X 3)$ secara bersamaan tidak memiliki pengaruh positif signifikan terhadap manajemen laba(Y) pada perusahan sektor aneka industri yang terdaftar di Bursa Efek Indonesia pada tahun 2015 - 2020.

Berdasarkan kesimpulan hasil penelitian yang telah dilakukan ada beberapa saran yang dapat diberikan.saran - saran yang dapat disampaikan adalah sebagai berikut :

1) Penelitian selanjutnya diharapkan dapat menggunakan jenis objek penelitian perusahaan yang lainnya seperti perusahaan jasa sebagai pembanding dan menggunakan priode penelitian terbaru agar dapat memberikan hasil yang lebih baik.

2) Untuk Penelitian selanjutnya dapat menggunakan lebih banyak variabel independen yang dapat mempengaruhi manajemen laba.

\section{DAFTAR PUSTAKA}

Aditama, Ferry \& Purwanungsih Anna. 2014. Pengaruh Perencanaan Pajak Terhadap Manajemen Laba Pada Perusahan Non Manufaktur Yang Terdaftar Di Bursa Efek Indonesia.Vol.26 (1)(33-50).

Agustia \& Suryani. 2018. Pengaruh Ukuran Perusahaan,Umur Perusahaan, Leverage Dan Profitabilitas Terhadap Manajemen Laba. Jurnal Aset (Akuntansi Riset): 63-74.

Amanda, Felicia, and Meiriska Febrianti. 2015. Analisis Pengaruh Beban Pajak Kini, Beban Pajak Tangguhan, dan Basis Akrual Terhadap Manajemen Laba. Jurnal ULTIMA Accounting 7(1): 70-86.

Anatasia, Diana dan Setiawati Lilis. 2017. Akuntansi Keuangan Menengah. Jakarta: CV Andi.

Arif, Rachmad dan Sugeng. 2015. Pengaruh Aktiva Pajak Tangguhan Terhadap Manajemen Laba. Vol. 4 No.7. 
Astutik, Ratna dan Eka Puji dan Mildawati Titik. 2016. Pengaruh Perencanaan Pajak Dan Beban Pajak Tangguhan Terhadap Manajemen Laba.Jurnal Akuntansi Vol.7: No.7.

Bauman, C.C., M.P. Bauman, and R.F. Halsey. 2001. Do Firms Use The Deferred Tax Assets Valuation Allowance to Manage Earning.JATA Vol. 23: 27-48.

Belkaoui, Ahmed R. 2007. Accounting Theory. Edisi lima. Salemba Empat.

Djamaluddin, Subekti. 2008. Analisis Perbedaan Antara Laba Akuntansi Dan Laba Fiskal Terhadap Persistensi Laba, Akrual, Dan Aliran Kas Pada Perusahaan Perbankan Yang Terdaftar Di Bursa Efek Indonesia. Jurnal Riset Akuntansi Indonesia Vol. 11 No: 52-74.

Fahmi, Irham. 2013. Pengantar Manajemen Keuangan. Bandung: Alfabeta.

Febriani, D. 2014. Pengaruh Manajemen Laba Terhadap Nilai Perusahaan Dengan Mekanisme Corporate Governance Sebagai Variabel Pemoderasi Pada Perusahaan Yang Terdaftar Di Bursa Efek Indonesia.

Fitriany, Lucy Citra. 2016. Pengaruh Aset Pajak Tangguhan, Beban Pajak Tangguhan, Dan Perencanaan Pajak Terhadap Manajemen Laba. Journal JOM Fekon 3(1): 1150-63.

Gay, LR, Geoffrey E. Mills and Peter Airasian. 2009. Educational Research, Competencies for Analysis and Application. New Jersey: Pearson Education, Inc.

Ghozali, Imam. 2009. Aplikasi Analisis Multivariate Dengan Program SPSS.

Ghozali, Imam. 2016. Aplikasi Analisis Multivariete Dengan Program IBM SPSS 22. Edisi 8. Semarang: Badan Penerbit Universitas Diponegoro.

Ghozali, Imam. 2017. Model Persamaan Struktural Konsep Dan Aplikasi Dengan Program AMOS 24. Semarang: Badan Penerbit Universitas Diponegoro.

Hakim, R.A. 2015. Pengaruh Aktiva Pajak Tangguhan Dan Beban Pajak Tangguhan Terhadap Manajemen Laba.Jurnal Ilmu dan Riset Akuntansi Vol. 4.

Hamzah, Ardi. 2014. Deteksi Manajemen Laba Melalui Beban Pajak Tangguhan, Akrual Dan Arus Kas Operasi. Jurnal Akuntansi Vol. 8.

Harnanto. 2003. Akuntansi Perpajakan. yogyakarta: BPFE- Yogyakarta.

Hartomo, Giri. 2019. "Kronologi Kasus Laporan Keuangan Garuda Indonesia Hingga Kena Sanksi." Okefinance. https://economy.okezone.com/read/2019/06/28/320/2072245/kronologikasus-laporan-keuangan-garuda-indonesia-hingga-kena-sanksi (March 15, 2021).

Healy, P.P and S.Wahlen. 1999. The Effect Of Bonus SCHEMES On Accounting Decision. Journal Of Accounting And Economic Vol.7 No.1: 28-47.

Ikatan Akuntansi Indonesia. 2010. PSAK No.46 Tentang Pajak Penghasilan.

Mahmudi. 2016. Akuntansi Sektor Publik Edisi Revisi. yogyakarta. 
Philips, Pincusdan S.O. Rego. 2003. Earning Management : New Evidence Based On Deferred Tax Expense.The Accounting Review No.78: 491-521.

Putra, R.H.D.K., dkk. 2019. Pengaruh Perencanaan Pajak Dan Beban Pajak Tangguhan Terhadap Manajemen Laba Pada Perusahaan Manufaktur Sub Makanan Dan Minuman Yang Terdaftar Di Bursa Efek Indonesia Periode 2013-2017.

Santoso, Singgih. 2012. Analisis SPSS pada Statistik Parametrik. Jakarta : PT. Elex Media Komput Indo.

Sari, R. N, .dkk. 2019. Pengaruh Beban Pajak Tangguhan, Perencanaan Pajak Dan Profitabilitas Terhadap Manajemen Laba Pada Perusahaan Manufaktur Yang Terdaftar Di Bursa Efek Indonesia Periode 2012-2017.

Sugiyono. 2015. Metode Penelitian Kombinasi ( Mix Methods). Bandung: Alfabeta.

Sugiyono. 2016a. Metode Penelitian Kuantitatif, Kualitatif Dan R\&D. Bandung: Penerbit Alfabeta.

Sugiyono. 2016b. Metode Penelitian Kuantitatif,Kualitatif Dan $R \&$ D. Bandung: Penerbit Alfabeta.

Suharsimi. 2016. Prosedur Penelitian: Suatu Pendekatan Praktik. Jakarta: Rineka Cipta.

Sulistyanto, H.sri. 2014. Manajemen Laba Teori Dan Metode Empiris. Jakarta: Grasindo.

Sulistyanto, sri. 2012. Manajemen Laba Teori Dan Model Empiris. Jakarta: Grasindo.

Suranggane, Zulaikha. 2007. Analisi Aktiva Pajak Tangguhan Dan Akrual Sebagai Prediktor Manajemen Laba. Jurnal Akuntansi dan Keuangan Indonesia Vol.4 No 1: 77-94.

Timuriana, Tiara, Dan Rezwan, and Rizki Muhamad. 2015. Describe the Effect of Deferred Tax Expense on Earnings Management in Manufacturing Companies in Indonesia Stock Exchange. Jurnal Ilmiah Akuntansi Fakultas Ekonomi 1(2): 12-20.

Tundjung, Ghafara Mawaridi Mazini. 2015. Pengaruh Beban Pajak Tangguhan Terhadap Manajemen Laba (Studi Empiris Pada Perusahaan Manufaktur Yang Terdaftar Di Bei).Diponegoro Journal of Accounting 4(2): 700-708.

Waluyo. 2014. Akuntansi Pajak. Jakarta: Salemba empat.

Yoppy, Purnawan. 2016. Pengaruh Aktiva Pajak Tangguhan, Beban Pajak Tangguhan Dan Basis Akrual Terhadap Manajemen Laba.

Yulianti. 2005. Kemampuan Beban Pajak Tangguhan Dalam Memprediksi Manajemen Laba.Jurnal Akuntansi dan Keuangan indonesia Vol.2 No.: 107-29.

https://www.idx.co.id/perusahaan-tercatat/laporan-keuangan-dan-tahunan/ https://www.idnfinancials.com/id/ 